\title{
O TAJEMNICZYM POPRZEDNIKU WIELKIEGO ŻUPANA SERBII STEFANA NEMANJI ZWANYM TIHOMIREM
}

\author{
BŁAŻEJ SZEFLIŃSKI
}

\begin{abstract}
On the Mysterious Predecessor of Grand Župan of Serbia Stephen Nemanja called Tihomir The paper is focused on the figure of the predecessor of grand župan Stephen Nemanja. The name of this mysterious person has not been preserved in any source. However mentions in different sources enable to research major facts in his life. On the basis of convergent evidence of several sources, his name can be reconstructed as Stephen Tihomir. He was born probably about 1105 as the first son of one of members of Vukanović dynasty - Stephen Vukan or Zavida. In his childhood he spent a few years in Zeta where his father escaped from Raška. There is no data about Tihomir until the year 1165 when he was appointed grand župan by the emperor Manuel Komnenos. During his short reign he was driven by his brothers to capture the youngest one - Nemanja. However Nemanja managed to flee and take over the throne. Nemanja's brothers had to escape. They came back with the Byzantine troops commanded by Theodor Padiates but they lost in the battle near Pantino. One of the brothers was drowned in the Sitnica river then. Most scholars believe it was Tihomir but more careful analysis of sources suggests it was another brother of Nemanja (maybe his name was Constantin), not his predecessor. It is hard to say what happened to Tihomir after the battle - maybe he lived in Skopie, maybe he came back to Serbia, acknowledged his youngest brother supreme power and received his own principality. If he had come back, he would have died before September $27^{\text {th }} 1186$.
\end{abstract}

Autor: Błażej Szefliński, bez akredytacji Łódź, e-mail: szeflin@o2.pl

Słowa kluczowe: Tihomir, Stefan Nemanja, Desa, wielki żupan, bitwa pod Pantino, inskrypcja, monaster Đurđevi Stupovi, Raszka

Keywords: Tihomir, Stephen Nemanja, Desa, grand župan, the Pantino battle, inscription, Djurdjevi Stupovi monastery, Raška

Balcanica Posnaniensia. Acta et studia, XXIII, Poznań 2016, Wydawnictwo Instytutu Historii UAM, pp. 35-45, ISBN 978-83-65663-26-9, ISSN 0239-4278. Polish text with a summary in English.

doi.org/10.14746/bp.2016.23.3

Przyglądając się serbskim badaniom mediewistycznym, można stwierdzić niedostatek prac o charakterze biograficznym. Dotyczy to również XII-wiecznych władców sprawujących urząd wielkiego żupana ${ }^{1}$. Jednym z nich był poprzednik Stefana

${ }^{1}$ Artykułów biograficznych doczekali się Vukan, Zavida (tylko część historyków uważa, że sprawował ten urząd), Urosz I, Urosz II (dwukrotnie), Belosz i Desa. J. Калић, Рашки велики жупан 
Nemanji - postać, o której niewiele wiadomo. Nie poświęcono mu dotąd osobnej pracy, a jedynie wspominano go przy okazji rozważania innych zagadnień, najczęściej związanych z rozwojem kariery politycznej Stefana Nemanji. W niniejszym artykule pragnę zebrać wszystkie informacje źródłowe dostarczające danych o tej tajemniczej osobie i ustalić, co tak naprawdę wiadomo o najstarszym bracie Stefana Nemanji, którego w historiografii przyjęło się nazywać Tihomirem.

Korpus źródeł, z których można się czegoś pośrednio lub bezpośrednio dowiedzieć o poprzedniku Stefana Nemanji, jest dość skromny. Obejmuje on krótkie fragmenty Epitomy Jana Kinnama, Historii Niketasa Choniatesa, Żywota św. Symeona pióra Stefana Nemanjicia, Żywota św. Symeona autorstwa Domencjana oraz inskrypcję nadgrobną żupana Stefana Prwosława.

W napisanej pomiędzy 1180 a 1183 r. $^{2}$ Epitomie znajdujemy następujący opis wydarzeń z 1163 roku$^{3}$ : Cesarz Manuel I Komnen prowadził wojsko bizantyńskie przeciwko Węgrom. Ponieważ wielki żupan Serbii imieniem Desa ociągał się z przysłaniem swoich oddziałów (jako wasal cesarski miał taki obowiązek) ${ }^{4}$, Manuel wezwał go do siebie do obozu rozbitego nieopodal Niszu. Po przybyciu Desie jednak nie wymierzono żadnej kary. Gdy nieco później do obozu cesarskiego dotarli posłowie węgierscy, Desa ośmielił się w rozmowie z nimi nazwać króla węgierskiego swoim panem. Za tę nielojalność został postawiony przed sądem cesarskim, a następnie umieszczony pod strażą $\mathrm{w}$ namiocie otoczonym wałem, gdzie był jednak na rozkaz cesarza traktowany z szacunkiem. Relacja kończy się stwierdzeniem, że n i e co później Desa został odesłany do Konstantynopola, gdzie wtrącono go do więzienia pałacowego $0^{5}$.

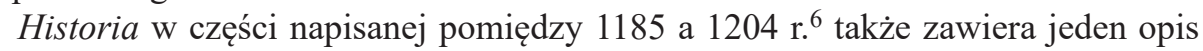
sądu cesarskiego nad Desą. Znacznie różni się on jednak od tego w Epitomie. Ustęp na ten temat znajduje się po relacji z oblężenia Zemunu przez Bizantyńczyków

Урош II, „Зборник радова Византолошког института” (dalej: ЗРВИ), 1970, t. 12, s. 21-39; idem, Жупан Белош, ЗРВИ, t. 36, 1997, s. 63-81; Т. Живковић, Портрети српских владара: (IX-XII век), Београд 2006.

2 Византијски извори за историју народа Југославије, t. IV, red. Г. Острогорски, Ф. Баришић, Београд 1971, s. 2 (dalej: ВИИНЈ, t. IV). Charles Brand zawęża datację do okresu regencyjnych rządów Marii, wdowy po cesarzu Manuelu I Komnenie, oraz jego bratanka protosebasta Aleksego Komnena, tj. od września 1180 do kwietnia 1182 r. John Kinnamos, The Deeds of John and Manuel Comnenus, trans. Ch. Brand, New York 1976, s. 4, 229.

${ }^{3}$ ВИИНЈ, t. IV, s. 60. Ch. Brand uważa to za wydarzenie z 1162 r. John Kinnamos, op. cit., s. 161162.

${ }^{4}$ Taki został wskazany powód bezpośredni. Oprócz tego Kinnam napisał o dwóch innych przewinieniach Desy - dalszym zajmowaniu Dendry, którą miał zwrócić, oraz negocjacjach z Niemcami. Biorąc pod uwagę problemy chronologiczne, o których piszę poniżej, nie można mieć pewności, czy te dwa przewinienia zostały prawidłowo połączone $\mathrm{z}$ sąsiednimi wydarzeniami, czy miały miejsce $\mathrm{w}$ innym momencie.

${ }^{5}$ ВИИНЈ, t. IV, s. 60-63; John Kinnamos, op. cit., s. 161-162.

${ }^{6}$ ВИИНЈ, t. IV, s. 108; О. Jurewicz, Historia literatury bizantyńskiej: zarys, Wrocław 2007, s. 234; A. Simpson, Before and After 1204: The Versions of Niketas Choniates ',Historia”, „Dumbarton Oaks Papers", 2006, t. 60, s. 189-221. 
w 1165 r., jednak nie ma pewności, czy jest z tym wydarzeniem chronologicznie powiązany. W każdym razie kronikarz napisał, że: Wielki żupan Desa w swym postępowaniu stał się gorszy od samego siebie (co oznacza, że dopuścił się występku po raz kolejny), co nie spodobało się cesarzowi Manuelowi (powód nie jest podany, zapewne chodziło o kontakty z Węgrami). W tej sytuacji zaniepokojony Desa poprosił przez posłów o pozwolenie na osobiste stawienie się przed cesarzem, a gdy je otrzymał, przybył ze zbrojnym orszakiem. Po odebraniu przysięgi wierności od Desy cesarz puścił go wolno. Relacja kończy się komentarzem autora wskazującym, że przysięga ta była nieszczera, co sugeruje, że w późniejszym czasie Desa był nielojalny. Jest to jednak ostatni ustęp w Historii mówiący o Desie ${ }^{7}$.

Z kolei wśród wydarzeń z 1168 r. zapisano, że ówczesny wielki żupan Stefan Nemanja zbuntował się i uderzył na Chorwację i Kotor. Cesarz wysłał więc wojsko pod wodzą Teodora Padiatesa. O rezultatach tej ekspedycji autor nie napisał, ale z dalszego przebiegu wydarzeń można wywnioskować, że Padiates został przez Serbów pokonany, wkrótce bowiem cesarz osobiście poprowadził armię przeciwko Nemanji. W celu uniknięcia konfrontacji wielki żupan ukorzył się przed cesarzem - jak dodaje kronikarz - obawiając się, aby Manuel nie przywrócił na tron tych, których Nemanja zrzucił, a którzy byli godniejsi od niego ${ }^{8}$.

Stefan Nemanjić w ukończonym przed 1217 r. ${ }^{9}$ Żywocie św. Symeona następująco opisał wydarzenia związane z narodzinami oraz wstąpieniem na tron przez jego ojca: Ojciec Nemanji stracił tron na skutek buntu swoich braci i musiał uciekać do Zety, gdzie urodził mu się kolejny potomek - Stefan Nemanja. Gdy ten jeszcze był dzieckiem, wrócili do Raszki. Później, w czasie swojego panowania nad dzielnicą obejmującą Toplicę, Rasinę, Ibar oraz Reki Nemanja wybudował cerkiew Bogurodzicy, a następnie zaczął wznosić również świątynię poświęconą św. Mikołajowi. To drugie przedsięwzięcie spotkało się ze sprzeciwem ze strony braci, którzy uważali, że Nemanja powinien wpierw uzyskać ich zgodę. Gdy Nemanja nie odstąpił od swoich zamiarów, bracia nakłonili najstarszego spośród nich, który był wówczas wielkim żupanem, aby wtrącił Nemanję do lochu. Ten jednak zdołał uciec z pieczary, w której go uwięziono, przejął władzę i przegnał braci. Po pewnym czasie bracia powrócili z wojskiem złożonym z Greków, Frugów (łacinników) i Turków. Zostali jednak pokonani przez Nemanję w bitwie niedaleko miejscowości Pantino. Jeden z braci w czasie bitwy utonął w rzece ${ }^{10}$.

\footnotetext{
${ }^{7}$ ВИИнј, t. IV, s. $138-139$.

${ }^{8}$ ВИИНЈ, t. IV, s. $144-148$.

9 B. Szefliński, Trzy oblicza Sawy Nemanjicia: postać historyczna - autokreacja - postać literacka, Łódź 2016, s. 175-176.

${ }^{10}$ Стефан Првовенчани, Сабрана дела, red. Љ. Јухас-Георгиевска, изд. Т. Јовановић, Београд 1999, s. 18-33 (tekst cerkiewnosłowiański i serbski przekład). Polski przekład niektórych fragmentów w: B. Szefliński, Chronologia życia Stefana Nemanji: próba uporządkowania, „Roczniki Historyczne”, 2014, t. 80 , s. 98 .
} 
W napisanym w 1263/1264 r. ${ }^{11}$ Żywocie św. Symeona Domencjan zawarł następujące dane. W czasie, gdy będący najmłodszym spośród braci Nemanja władał ziemiami na wschodzie, jego bracia sprzymierzyli się przeciw niemu. Nemanja wybudował cerkiew Bogurodzicy, a następnie drugą - św. Mikołaja. Zostało to odczytane przez braci jako wynoszenie się ponad nich. W porozumieniu z najstarszym z nich, który był wówczas wielkim żupanem, schwytali więc Nemanję, zakuli w kajdany i uwięzili w jaskini. Nemanja jednak zdołał uciec i przegnał braci, rozpraszając ich po obcych krajach. Część spośród rozproszonych zebrała się w greckiej ziemi, gdzie mieli nadzieję otrzymać wsparcie. Zgromadziwszy znaczne siły złożone z Greków, Frugów (łacinników), Turków i innych nacji, ruszyli przeciw Nemanji. Gdy dotarli do Pantino, Nemanja pobił ich w bitwie. Oprócz poległych od miecza wielu nieprzyjaciół Nemanji zginęło wówczas w wodach rzeki Sitnicy. Jednym z nich był ich przywódca $^{12}$.

W monasterze św. Jerzego (Đurđevi Stupovi) w Budimlji znajduje się nie w pełni zachowana inskrypcja następującej treści: „,.. 6 dnia przeszedł [do innego świata] sługa Boży Stefan żupan Prwosław, syn wielkiego ... ...omira, bratanek świętego Symeona Nemanji i ktitor miejsca tego; oto i grób jego jest" ${ }^{13}$. Napis ten datuje się na schyłek XVI w. lub początek stulecia XVII ${ }^{14}$. Zapewne jest to kopia pierwotnej inskrypcji wykonanej krótko po śmierci Stefana Prwosława, która miała miejsce po hierofanii św. Symeona, a przed nadaniem monasterowi św. Jerzego statusu cerkwi biskupiej ${ }^{15}$, czyli między lutym 1207 a 1220 r. $^{16}$

$$
* * *
$$

Najstarszy brat Nemanji przyszedł na świat prawdopodobnie około 1105 r. ${ }^{17}$ jako pierwszy syn będącego członkiem dynastii Vukanoviciów władającej Raszką Stefana

11 B. Szefliński, Trzy oblicza, s. 188, przyp. 41.

12 Доментијан, Животи Светога Симеуна и Светога Саве, red. Ђ. Даничић, Биоград 1865 , S. 4-20.

13 Rekonstrukcja całości tekstu zaproponowana przez Gordanę Tomović (w nawiasach ostrokątnych

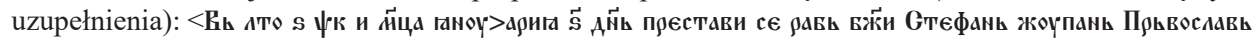

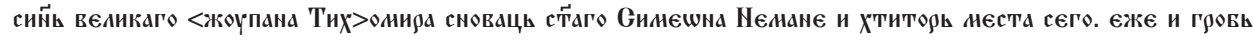
єго ю̈ть. С. Пириватрић, О Стефану Првославу, ктитору иркве Светог Георгија у Будимљи, w: Ђурђеви ступови и Будимљанска епархија: зборник радова, red. М. Радујко, Беране-Београд 2011, s. 54. W polskim przekładzie brzmiałoby to: „W roku 6728 [tj. 1220] miesiąca stycznia 6 dnia przeszedł [do innego świata] sługa Boży Stefan żupan Prwosław, syn wielkiego żupana Tihomira, bratanek świętego Symeona Nemanji i ktitor miejsca tego; oto i grób jego jest".

14 Spis wcześniejszych wydań tekstu wraz z podanymi tam datacjami: С. Пириватрић, О Стефану Првославу, s. 53, przyp. 1.

15 Ibidem, s. 53, 65-66.

16 B. Szefliński, Trzy oblicza, s. 76, przyp. 212; 88-89, 113-114. Zważywszy na to, że hierofania Symeona miała miejsce 13 lutego, a Stefan Prwosław zmarł 6 stycznia, datowanie jego śmierci na rok 1207 można praktycznie wykluczyć.

17 Najmłodszy z braci, Nemanja, urodził się w 1112 lub na początku 1113 r. B. Szefliński, Chronologia, s. $95-110$. 
Vukana lub Zavidy ${ }^{18}$. Zapewne był razem z ojcem, gdy ten uciekł przed swoimi braćmi do Zety po zrzuceniu z tronu. Po kilku latach pobytu na wygnaniu powrócił do Raszki. Zapewne najstarszy syn mu towarzyszył. Na temat następnych czterdziestu kilku lat życia poprzednika Nemanji nie dysponujemy żadnymi informacjami.

Rozpoczynając rozważania nt. wydarzeń z lat 60. XII w., nie można przemilczeć, że w przytoczonych powyżej przekazach źródłowych pojawiają się informacje, które sprawiają wrażenie niepełnych i niedokładnych. Jeśli bowiem całkowicie wierzyć narracji Choniatesa, to można by pomyśleć, że w 1165 r. Desa pozostał na tronie, a następnym wielkim żupanem był Nemanja, który trzy lata później panował już od pewnego czasu. To jednak oznaczałoby, że Desa musiałby być najstarszym bratem Nemanji, o którym mówią żywoty św. Symeona. Tak jednak być nie mogło - z różnych źródeł wiadomo, że Desa miał braci Urosza II, Primisława i Belosza, a braćmi Nemanji byli Mirosław ${ }^{19}$ oraz Stracimir. Nic nie wskazuje na to, aby Desa i Nemanja byli braćmi. Ponadto nazwanie tego pierwszego „ostatnim z braci” przez Kinnama sugeruje, że nie był on pierworodny ${ }^{20}$. Biorąc powyższe pod uwagę, należy stwierdzić, że poprzednikiem Nemanji na wielkożupańskim tronie był nie Desa, a ktoś inny.

Z przekazem Choniatesa na temat sądu nad Desą wiąże się także druga wątpliwość - niezgodność z piszącym wcześniej Kinnamem. Czy to w ogóle możliwe, że w 1163 r. Desa został odesłany do więzienia w Konstantynopolu, a w dwa lata później znów zasiadał na tronie, ponownie był sądzony za przewinienie wobec cesarza i tym razem suwerenowi wystarczyła przysięga wierności? Wydaje się to nierealne. W nowszych pracach kilkukrotnie zwracano uwagę na rozbieżność opisów sądu nad Desą w tych dwóch źródłach i proponowano różne rozwiązania. Ferenc Makk, Jan Leśny oraz Paul Stephenson, jak się zdaje, skłaniali się ku jednemu tylko sądowi cesarskiemu, który miał miejsce w 1165 r. (jak u Choniatesa) i zakończył się odesłaniem Desy do Konstantynopola (jak u Kinnama) ${ }^{21}$. Według dwóch ostatnich rozwiązanie takie sugeruje również dwukrotnie pojawiające się w narracji Kinnama wyrażenie „nieco później” - albo przy pierwszym wystąpieniu (tak Stephenson), albo przy drugim (tak Leśny). Srđan Pirivatrić dopuszcza dwie możliwe datacje detronizacji Desy - 1163 lub 1165 r. ${ }^{22}$. Natomiast Tibor Živković przedstawił pogląd, który jak się zdaje, naj lepiej wyjaśnia aluzje zawarte w źródłach. Według tego badacza kronikarze opisali 2 różne wydarzenia, które jednak, w obu przypadkach, zostały naj-

18 B. Szefliński, Kilka uwag na rzecz rehabilitacji zapomnianej filiacji Stefana Nemanji, „Balcanica Posnaniensia", t. 22/2, 2015, s. 5-14.

${ }^{19}$ Osobny problem stanowi znalezienie odpowiedzi na pytanie: czy Mirosław był rodzonym bratem Nemanji, czy np. stryjecznym? B. Szefliński, Kilka uwag, s. 5-14.

20 John Kinnamos, op. cit., s. 155.

${ }^{21}$ F. Makk, The Árpáds and the Comneni: Political Relations beetween Hungary and Byzantium in the 12th Century, Budapest 1989, s. 159, 168-169; J. Leśny, Studia nad poczatkami serbskiej monarchii Nemaniczów: (połowa XI - koniec XII wieku), Wrocław 1989, s. 151-152; P. Stephenson, Byzantium's Balkan Frontier: a Political Study of the Northern Balkans, 900-1204, Cambridge 2000, s. 266-267.

22 С. Пириватрић, Једна претпоставка о пореклу бугарског изара Константина Асена «Тиха», ЗРВИ, 2009, t. 46, s. 318. 
prawdopodobniej źle usytuowane w chronologii. Miałyby one się odbyć w odwrotnej kolejności, tzn. sąd zrelacjonowany przez Choniatesa miałby miejsce w 1163 r., a ten zapisany u Kinnama - w $1165 \mathrm{r}^{23}$

Jeśli tak faktycznie było, to w $1165 \mathrm{r}$. cesarz pozbawił Desę tronu. Logiczne wydaje się, że jednocześnie wyznaczył jego następcę. Nie mógł jednak być to Nemanja, bo ten przejął władzę siłą. Nowym wielkim żupanem musiał zostać najstarszy brat Nemanji. O jego panowaniu wiadomo tylko tyle, że uwięził najmłodszego z braci z powodu budowy cerkwi św. Mikołaja. Według Stefana Nemanjicia nastąpiło to po rozpoczęciu budowy, a według Domencjana - po zakończeniu. Wydaje się, że rzeczywisty przebieg wydarzeń ujęto w pierwszym źródle. Relacja ta powstała wcześniej i jest bardziej logiczna. Z przekazem Domencjana wiąże się również pewna trudność chronologiczna - trudno sądzić, że w czasie krótkiego panowania swojego brata Nemanja zdążyłby wznieść cerkiew Bogurodzicy (nawet jeśli budowa była rozpoczęta już wcześniej), a następnie od początku do końca wybudować drugą świątynię.

Panowanie poprzednika Nemanji zakończyło się, gdy został zrzucony z tronu, co nastąpiło najpóźniej w $1168 \mathrm{r}$. W historiografii przyjęło się stanowisko, że udał się on do Bizancjum, skąd powrócił wraz z wojskiem ${ }^{24}$. Jest to prawdopodobne. Warto jednak zwrócić uwagę, że informacja taka nie pojawia się explicite w żadnym źródle, a Domencjan wyraźnie zaznaczył, że nie wszyscy nieprzyjaciele Nemanji zgromadzili się w Bizancjum.

Co się natomiast tyczy wojska, które ze sobą przyprowadzili, to serbska historiografia zgodnie przyjmuje, że był to oddział pod wodzą Padiatesa wspomniany przez Choniatesa ${ }^{25}$. Odmienne stanowisko przedstawił J. Leśny, który sądził, że najpierw zostali pokonani bracia Nemanji, a później dopiero Padiates. Polski badacz argumentował, że źródła nic nie wspominają o uzyskaniu przez braci wsparcia bizantyńskiego, więc musieli działać na własną rękę ${ }^{26}$. Trzeba tu jednak zauważyć, że obaj hagiografowie mieli powód, aby tę informację zataić (zburzyłaby ona zbudowany we wcześniejszych partiach tekstu obraz działania cesarza Manuela jako czynnika legitymizującego władzę Nemanji), a w narracji Choniatesa mogła się nie znaleźć jako stosunkowo mało istotna. Jednocześnie polski uczony sam też zauważył, że skład etniczny oddziałów przyprowadzonych przez braci odpowiada temu, co wiemy o ówczesnej

23 Т. Живковић, op. cit., s. 148-149.

${ }^{24}$ Историја српског народа, t. 1: Од настаријих времена до Маричке битке (1371), Београд 1981, s. 209; J. Leśny, op. cit., s. 173-174; J. Fine Jr, The Late Medieval Balkans: A Critical Survey from the Late Twelfth Century to the Ottoman Conquest, Ann Arbor 1994, s. 5; Б. Ферјанчић, Стефран Немања у византијској политиции друге половине ХІІ века, w: Стефан Немања - Свети Симеон Мироточиви. Историја и предање, red. Ј. Калић, Београд 2000, s. 34; М. Благојевић, Д. Медаковић, Историја српске државности, t. 1: Од настанка првих држава до почетка српске начионалне револуичје, Нови Сад 2000, s. 90-91.

25 J. Калић, Српско-византијски сукоб 1168. године, „Зборник Филозофског факултета”, t. 11/1, 1970, s. 200; С. Пириватрић, Прилог хронологији почетка Немањине власти, ЗРВИ, 1991, t. 29-30, s. 132-133; Б. Ферјанчић, op. cit., s. 34.

26 J. Leśny, op. cit., s. 173-175. 
armii bizantyńskiej ${ }^{27}$. Ponieważ nie przedstawiono dotąd żadnych argumentów, które kazałyby odrzucić pogląd przyjęty w serbskiej historiografii, nie widzę powodów, by zakładać, że były to różne pochody.

Równie ugruntowany jest w historiografii pogląd, że poprzednik Nemanji utopił się w czasie bitwy w Sitnicy ${ }^{28}$. Jestem jednak zdania, że źródła wskazują na coś innego. Stefan Nemanjić stwierdził, że utonął jeden z braci, podczas gdy wcześniej najstarszego z nich wyraźnie odróżniał. Co więcej śmierć poprzednika, który niesprawiedliwie uwięził Nemanję za pobożność, i to śmierć w nurtach rzeki byłaby „na rękę” hagiografowi, który mógłby opisać ją jako karę boską. Tak jednak nie uczynił, co sugeruje, że w rzece zginął inny z braci Nemanji. Również Domencjan nie przekazuje informacji, które by wskazywały, że utonął najstarszy brat Nemanji. W użytym przez

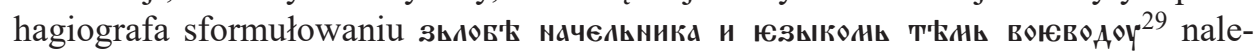
ży raczej widzieć inicjatora spisku przeciwko Nemanji, a nie poprzedniego wielkiego żupana, który zdaje się, zaakceptował po prostu żądania swych braci. Wzmianka u Choniatesa o tych, których Nemanja zrzucił z tronu, a którzy byli godniejsi od niego, może dotyczyć także najstarszego z braci.

W związku z powyższym rodzi się pytanie: na jakiej podstawie sformułowano pogląd, że to poprzednik Nemanji utonął w rzece? Tezę taką przedstawił Ljubomir Kovačević3 ${ }^{30}$, wskazując, że późniejsze źródła - rodosłowy (karłowicki, zagrzebski, Pajsija, vrhobreznicki, dodatek do Pajsija, Pejatovicia, Novakovicia) ${ }^{31}$, bazujące na nich młodsze latopisy ${ }^{32}$ oraz Królestwo Stowian autorstwa Maura Orbiniego ${ }^{33}-$ wymieniają dokładnie trzech braci Nemanji. Z kolei ze źródeł współczesnych wydarzeniom wiadomo, że dwaj bracia Nemanji - Mirosław i Stracimir - w latach 80. XII w. wciąż jeszcze żyli ${ }^{34}$. W związku z tym utonąć musiał trzeci z braci. Miałby to być ojciec Stefana Prwosława wspomniany w przywołanej wyżej inskrypcji w monasterze św. Jerzego, którego imię Lj. Kovačević zrekonstruował jako „Tihomir“.

27 Ibidem, s. 173-174.

28 Ibidem, s. 174; J. Fine Jr, op. cit., s. 5; Б. Ферјанчић, op. cit., s. 34; М. Благојевић, Д. Медаковић, op. cit., s. 91.

29 Доментијан, ор. cit., s. 20.

30 Љ. Ковачевић, Неколико питања о Стефану Немањи, „Глас Српске краљевске академије”, 1900 , t. 58, s. $48-56$.

31 Љ. Стојановић, Стари српски родослови и летописи, Сремски Карловци 1927, s. 14-17 (nr 7), 20-21 (nr 9), 40 (nr 26), 46 (nr 42, 44), 57 (nr 103). Zaczęły one powstawać pomiędzy 1373 a 1377 r. i były rozwijane w późniejszym okresie. Trudno ustalić, kiedy wprowadzono informację o braciach Nemanji. Ђ.Сп. Радојичић, Доба постанка и развој старих српских родослова, w: idem, Књижевна збивања и стварања код Срба у средњем веку и у турско доба, Нови Сад 1967, s. 157-178.

32 љ. Стојановић, op. cit., s. 175 (nr 422), 181 (nr 448), 197 (nr 522), 202 (nr 559), 279 (nr 1059), 280 (nr 1061). Tylko w niektórych latopisach wymieniono pięciu braci - oprócz trzech obecnych w innych źródłach dodatkowo Tehomila i C̆udomila, których inne latopisy zaliczają do przedstawicieli poprzedniego pokolenia. Ibidem, s. 191 ( $\mathrm{nr} 487), 193$ (nr 504).

33 Mavro Orbini, Kraljevstvo Slavena, prev. S. Husić, prir. i uvod F. Šanjek, Zagreb 1999, s. 310311.

34 Zob. niżej przyp. 39 i 40. 
Trzeba jednak zauważyć, że chociaż źródła zgadzają się co do liczby braci, to są całkowicie rozbieżne pod względem ich imion. Według rodosłowów i latopisów bracia Nemanji nazywali się Zavid, S(t)racimir i Prwosław, a wedle Orbiniego - Tihomil, Konstantyn i Mirosław. Łatwo zauważyć, że z obu trójek tylko po jednym z braci znajdujemy w źródłach współczesnych wydarzeniom. O następnych dwóch wiadomo, że w rzeczywistości łączyło ich z Nemanją inne pokrewieństwo - Zavida był jego stryjem lub ojcem ${ }^{35}$, a Prwosław bratankiem. Biorąc pod uwagę fakt, że rodosłowy i latopisy podają, że ojcem Nemanji był Tehomil ${ }^{36}$, jest całkiem prawdopodobne, że Nemanja miał bliskiego krewnego Tihomila/Tehomila. Imię to można uznać za zniekształcone brzmienie formy zaproponowanej przez Kovačevicia, która byłaby zgodna z inskrypcją z monasteru św. Jerzego. W związku z powyższym należy stwierdzić, że pięć z sześciu imion „braci“ Nemanji należało do jego bliskich krewnych. Rodzi się pytanie: dlaczego w przypadku szóstego miałoby być inaczej? Kovačević sądził, że imię Konstantyna znalazło się w kronice Orbiniego za sprawą kombinacji autora, który z jednej strony znał podania przypisujące powstanie niektórych serbskich świątyń cesarzowi/carowi Konstantynowi, a $z$ drugiej sądził, że były to fundacje brata Nemanji ${ }^{37}$. Mogło tak być, ale dowodów nie ma. Równie zasadne jest przypuszczenie, że Nemanja rzeczywiście miał brata o imieniu Konstantyn. To by oznaczało, że w rzece utonąć mógł nie tylko jeden z braci („ten trzeci“), ale jeden z dwóch, o których aktywności po $1168 \mathrm{r}$. brak danych w ówczesnych źródłach.

Wracając jednak do losów poprzednika Nemanji, trzeba stwierdzić, że nie wiadomo, co się z nim stało po 1168 r. Niedawno S. Pirivatrić przedstawił hipotezę, że działający około 1200 r. w Skopiu archont Jan Tihomir (lub Jan, syn Tihomira) był potomkiem wielkiego żupana Tihomira ${ }^{38}$. Jeśli poprzednik Nemanji przeżył bitwę pod Pantino, to mógł zamieszkać wraz z rodziną w Skopiu. Druga możliwość jest taka, że podobnie jak Mirosław i Stracimir uznał zwierzchnictwo Nemanji. Wówczas mógł powrócić do Serbii i otrzymać własną dzielnicę. Fakt, że ówczesne źródła o nim nie wspominają, wcale nie wyklucza możliwości jego powrotu do Serbii, ponieważ pierwsza wzmianka o Mirosławie po 1168 r. dotyczy dopiero roku $1181^{39}$, a o Stracimirze roku $1186^{40}$, mimo że najprawdopodobniej przebywali oni przez ten czas w Serbii. Poprzednik Nemanji musiałby jednak umrzeć przed 27 września 1186 r., ponieważ w odróżnieniu od Mirosława i Stracimira - jego imię nie figuruje w zawartym wów-

35 Szerzej na ten temat B. Szefliński, Kilka uwag, s. 5-14.

36 Љ. Стојановић, op. cit., s. 14-17 (nr 7), 40 (nr 26), 46 (nr 42), 57 (nr 103), 175 (nr 422), 202 (nr 559), 279 (nr 1059).

37 Љ. Ковачевић, op. cit., s. 50, przyp. 4.

${ }^{38}$ С. Пириватрић, Једна претпоставка, s. 319-324.

${ }^{39}$ Codex diplomaticus regni Croatiae, Dalmatiae et Slavoniae, vol. 2: Diplomata saeculi XII. continens (1101-1200), Coll. T. Smičiklas, Zagrabiae 1904, s. 176 (dok. nr 174).

40 Зборник средњовековних ћириличких повеља и писама Србије, Босне и Дубровника, t. 1: 1186-1321, red. В. Мошин, С. Ћирковић, Д. Синдик, Д. Синдик, Београд 2011, s. 45-48 (dok. nr 1). 
czas układzie pokojowym pomiędzy Serbią a Dubrownikiem ${ }^{41}$, co dowodzi, że nie było go wówczas w strukturach władzy.

Na koniec wypada poruszyć kwestię brzmienia inskrypcji w monasterze św. Jerzego. Biorąc pod uwagę fakt, że późniejsze źródła wymieniają jako bliskiego krewnego Nemanji Tihomila/Tehomila, rekonstrukcja imienia dokonana przez Kovačevicia jest dość prawdopodobna, jednak stuprocentowej pewności co do jej poprawności, bez odkrycia nowych źródeł, mieć nie można ${ }^{42}$. W najnowszej rekonstrukcji tekstu inskrypcji jeden element jest jednak zastanawiający. Napis wykonano w dwóch wierszach, które zostały uszkodzone do tej samej szerokości, co sugeruje, że w obydwu wierszach brakuje podobnej liczby znaków. Tymczasem w najnowszej rekonstrukcji zaproponowano 16 znaków (tu i dalej or liczę jako dwa znaki) w pierwszym wierszu i $10 \mathrm{w}$ drugim. Przypuszczam, że w rekonstrukcji tej czegoś brakuje w drugim wierszu. Biorąc pod uwagę fakt, że Nemanja i jego rodzony brat Stracimir mieli to samo imię kalendarzowe (Stefan $)^{43}$, jest wielce prawdopodobne, że pozostali bracia również to imię nosili. W związku z tym uważam za możliwą następującą rekonstrukcję:

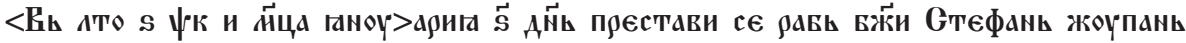
Прьвославь син̆́ великаго

<жоүпана Gтефана Тих>омира сноваць ст̈аго Gияешна Ненане и Хтиторь места сєго. єжє и грови єго Ёть.

W tym przypadku do zachowanego tekstu dodajemy 16 znaków w pierwszym wierszu i 17 w drugim. Datę roczną powtarzam za G. Tomović, choć jak wskazałem powyżej możliwe są daty z przedziału $1208-1220$.

Podsumowując, najstarszy brat Nemanji prawdopodobnie nazywał się Stefan Tihomir. Przyszedł na świat prawdopodobnie około 1105 r. W dzieciństwie spędził zapewne kilka lat na terenie Zety. Na arenie politycznej pojawia się w źródłach dopiero w latach 60. XII w. W 1165 r. został mianowany przez cesarza Manuela Komnena wielkim żupanem Serbii. Za namową braci uwięził najmłodszego - Nemanję - co pociągnęło za sobą przewrót, na skutek którego musiał ratować się ucieczką, najprawdopodobniej do Bizancjum. Wygnani bracia Nemanji, wśród których prawdopodobnie był również Tihomir, powrócili z wojskiem, ale zostali pokonani w bitwie pod Pantino. Wbrew powszechnemu przekonaniu Tihomir raczej wtedy nie utonął W rzece - prawdopodobnie spotkało to innego z braci, który być może miał na imię Konstantyn. Dalsze losy Tihomira nie są pewne - być może zamieszkał w Skopiu, ale możliwe też, że uznał zwierzchnictwo Nemanji i otrzymał dzielnicę podobnie jak jego bracia. We wrześniu $1186 \mathrm{r}$. nie było go w serbskich strukturach władzy, więc - jeśli powrócił do swojej ojczyzny - musiał już wtedy nie żyć.

${ }^{41}$ Ibidem, s. 45-48 (dok. nr 1).

$42 \mathrm{O}$ ile mi wiadomo, przede mną tylko dwaj badacze przyjęli rekonstrukcję zaproponowaną przez Kovačevicia z pewną dozą rezerwy. Д. Анастасијевић, Отаи Неманин, Београд 1914, s. 18-19; С. Пириватрић, Једна претпоставка, s. 318. Reszta historiografii przyjmuje ją bez zastrzeżeń.

${ }^{43}$ B. Szefliński, Kilka uwag, s. 8-9. 


\section{BIBLIOGRAFIA}

\section{Źródła}

Codex diplomaticus regni Croatiae, Dalmatiae et Slavoniae, vol. 2: Diplomata saeculi XII. continens (1101-1200), Coll. Tade Smičiklas, Zagrabiae 1904.

John Kinnamos, The Deeds of John and Manuel Comnenus, trans. Charles Brand, New York 1976.

Mavro Orbini, Kraljevstvo Slavena, prev. Snježana Husić, prir. i uvod Franjo Šanjek, Zagreb 1999.

Византијски извори за историју народа Југославије, t. IV, red. Георгије Острогорски, Фрањо Баришић, Београд 1971.

Доментијан, Животи Светога Симеуна и Светога Саве, изд. Ђуро Даничић, Биоград 1865.

Зборник средњовековних ћириличких повеља и писама Србије, Босне и Дубровника, t. 1: 1186-1321, red. Владимир Мошин, Сима М. Ћирковић, Душан Синдик, Душан Синдик, Београд 2011.

Стефан Првовенчани, Сабрана дела, red. Љиљана Јухас-Георгиевска, изд. Томислав Јовановић, Београд 1999.

Стојановић Љубомир, Стари српски родослови и летописи, Сремски Карловци 1927.

\section{Opracowania}

Fine Jr John, The Late Medieval Balkans: A Critical Survey from the Late Twelfth Century to the Ottoman Conquest, Ann Arbor 1994.

Jurewicz Oktawiusz, Historia literatury bizantyńskiej: zarys, Wrocław 2007.

Makk Ferenc, The Arpáds and the Comneni: Political Relations beetween Hungary and Byzantium in the 12th Century, Budapest 1989.

Leśny Jan, Studia nad początkami serbskiej monarchii Nemaniczów: (połowa XI - koniec XII wieku), Wrocław 1989.

Simpson Alice, Before and After 1204: The Versions of Niketas Choniates' „Historia”, „Dumbarton Oaks Papers", t. 60, 2006, s. 189-221.

Stephenson Paul, Byzantium's Balkan Frontier: a Political Study of the Northern Balkans, 900-1204, Cambridge 2000.

Szefliński Błażej, Chronologia życia Stefana Nemanji: próba uporządkowania, „Roczniki Historyczne”, t. 80,2014 , s. $95-110$.

Szefliński Błażej, Kilka uwag na rzecz rehabilitacji zapomnianej filiacji Stefana Nemanji, „Balcanica Posnaniensia", t. 22/2, 2015, s. 5-14.

Szefliński Błażej, Trzy oblicza Sawy Nemanjicia: postać historyczna - autokreacja - postać literacka, Łódź 2016.

Анастасијевић Драгутин, Отаи Немањин, Београд 1914.

Благојевић Милош, Медаковић Дејан, Историја српске државности, t. 1: Од настанка првих држава до почетка српске начионалне револуиије, Нови Сад 2000.

Историја српског народа, t. 1: Од настаријих времена до Маричке битке (1371), Београд 1981.

Калић Јованка, Жупан Белош, „Зборник радова Византолошког института”, t. 36, 1997, s. 63-81.

Калић Јованка, Рашки велики жупан Урош II, „Зборник радова Византолошког института”, t. 12, 1970, s. 21-39.

Калић Јованка, Српско-византијски сукоб 1168. године, „Зборник Филозофског факултета”, t. 11/1, 1970, s. 193-204.

Ковачевић Љубомир, Неколико питања о Стефану Немањи, „Глас Српске краљевске академије”, t. 58,1900 , s. $1-107$.

Пириватрић Срђан, Једна претпоставка о пореклу бугарског ичара Константина Асена „Тиха”, „Зборник радова Византолошког института”, t. 46, 2009, s. 313-331.

Пириватрић Срђан, О Стефану Првославу, ктитору иркве Светог Георгија у Будимљи, w: Ђурђеви ступови и Будимљанска епархија: зборник радова, red. Милан Радујко, Беране-Београд 2011, s. 53-67. 
Пириватрић Срђан, Прилогхронологији почетка Немањине власти, „Зборник радова Византолошког института“, t. 29-30, 1991, s. 125-135.

Радојичић Ђорђе Сп., Доба постанка и развој старих српских родослова, w: idem, Кьижевна збивања и стварања код Срба у средњем веку и у турско доба, Нови Сад 1967, s. 157-178.

Ферјанчић Божидар, Стефан Немањ а у византијској политици друге половине XII века, w: Стефан Немања-Свети Симеон Мироточиви. Историја и предање, red. Јованка Калић, Београд 2000, s. $31-45$. 
